\title{
CERTAIN ECOLOGICAL ASPECTS FOR Icerya seychellarum (Westwood) ON COFFEE PLANTS Coffea arabica IN EGYPT Nabil, Dalia Z. ${ }^{2}$; A. H. Amin ${ }^{1}$; Y. E. Y. Abdallah ${ }^{1}$ and Nagwa A. Hassan ${ }^{2}$ \\ 1- Dept. Plant Protection, Fac. of Agric., Ain Shams Univ., Cairo, Egypt \\ 2- Dept. Scale Insects \& Mealybugs, Plant Protection Research Institute, Giza, Egypt
}

\begin{abstract}
Certain ecological aspects of the Seychellarum mealybug, Icerya seychellarum (Westwood) which is considered as a key pest on coffee trees, a promising newly crop cultivated in Egypt, have been investigated under two different ecosystems throughout two years, 2009 \& 2011.

Results revealed that this mealybug species was found all the year round in both localities. The total population recorded four peaks of seasonal abundance in both investigated ecosystems on coffee trees and it passed through three overlapping generations in both ecosystems.

The main weather factors, four weeks earlier, showed miscellaneous effects on the population dynamics of this mealybug species. Means of minimum and maximum temperature had a positive significant effect; while mean percentage of relative humidity showed insignificant effect in the two localities. The combined effects of the four weather factors, as a group, had significant effects on I. seychellarum population throughout both years. In Qalyubyia Governorate (2009), the percentage of explained variance was $56.8 \%$; while in Giza Governorate (2011), this value was $65.9 \%$.

Keywords: Coffea arabica, Icerya seychellarum, population dynamics, seasonal abundance, generations, weather factors.
\end{abstract}

\section{INTRODUCTION}

Coffee trees (Coffea arabica L.) are cultivated in tropical and subtropical countries (Ethiopia, Kenya, Yemen, India, Colombia, Costa Rica and Brazil). These trees need special environmental conditions especially partial shade. The relationships between climatic parameters and agricultural production is further complicated because these environmental factors influence the growth and yield. The development of coffee trees varies in different ways during the various growth stages of the coffee crop (Camargo, 2010). In some regions, such as in Brazil, $C$. arabica trees are frequently grown without shade. These trees tend to mature earlier and to produce larger yields, but they also tend to decline at a younger age than those grown in shade (Sauer, 1993). In 2009/10 coffee accounted for exports worth an estimated $\$ 15.4$ billion, when some 93.4 million bags were shipped, with total coffee sector employment estimated at about 26 million people in 52 producing countries (ICO, 2012).

In Egypt, few numbers of $C$. arabica trees were cultivated at the Botanical Garden in Aswan on the beginning of the twentieth century. Ibrahim et al. (1987) reported that all coffee trees are successfully adapted to partial shade condition under mango trees. Therefore, they cultivated 4 feddans at 
Nabil, Dalia Z. et al.

El-Kanater El-Khairia district, Qalyubyia Governorate. The yield of each tree ranged between 6 to $10 \mathrm{~kg} / \mathrm{year}$. They added that shades of other local cultivations such as palm trees may provide enough shelter to protect coffee bushes against sun. This new promising crop began to wide-spread in Egypt especially in newly reclaimed lands.

Coffee trees are infested with wide range of pests in tropical and subtropical regions throughout the world. These pests include scale insects, mealybugs, stem borers, leaf miners and nematodes. Fletcher (1974) stated that number of insects and mite pest species on coffee trees worldwide reach 838 species. Recently, Waller et al. (2007) mentioned that over 3000 species of insects and mites with other predators and parasites are associated with coffee trees worldwide.

Preliminary survey of insect pests that were found to attack coffee trees in Egypt showed that these trees are infested by three main insect pests; i.e. the green shield scale, Chloropulvinaria psidii (Maskell), Seychellarum mealybug, Icerya seychellarum (Westwood) and Striped mealybug, Ferrisia virgata (Cockerell). The I. seychellarum seemed to be a key pest on coffee tree during the last few years.

Therefore, the present investigation is an attempt to explore certain ecological aspects of this key pest on coffee in Egypt for this new promising crop under local environmental conditions along with the effect of main weather factors on its population dynamics.

\section{MATERIALS AND METHODS}

\section{a. Seasonal activity and field generations}

Studies on the Seychelles fluted scale, Icerya seychellarum were carried out throughout two years, 2009 and 2011. These studies were conducted under two different ecosystems. In the first year was conducted under field conditions on coffee trees at Qalyubyia Governorate throughout one complete year (from $1^{\text {st }}$ of January to mid-December, 2009); while the second season was conducted under nursery conditions on coffee bushes at Giza Governorate throughout another one complete year (from $15^{\text {th }}$ of January 2011 to $1^{\text {st }}$ of January 2012).

To investigate the seasonal fluctuations of different developmental stages and number of annual generations of $I$. seychellarum on coffee trees, a coffee orchard of about 4 feddans (about 40 years old) was chosen for these studies. Trees were intercropped under the shade of mango threes which was about 60 years old. This orchard is located at El-Qanater ElKhairiya district, Qalyubiya Governorate (about $15 \mathrm{~km}$ to the north of Cairo) and is affiliated as the Experimental Station of the Horticulture Research Institute, Agriculture Research Center. Five coffee trees of the same size, height, vegetation and age were selected to represent the whole orchard and used for regular sampling procedures. All agricultural practices were conducted as usual except insecticidal application. Sampling procedures were applied from $1^{\text {st }}$ of January to $15^{\text {th }}$ of December, 2009. Half-monthly samples of 50 infested leaves were picked up at random from the five 
selected trees (10 leaves/tree). Samples represented the different heights and directions of the trees. These samples were put in polyethylene bags and transferred to the laboratory for investigation. Different developmental stages were sorted and counted using stereoscopic microscope. Unfortunately this orchard was sharply pruned and sprayed after the last sample. Therefore, the ecological studies during the second year were continued under nursery conditions.

A nursery at the Plant Protection Research Institute, Dokki (Giza Governorate) was chosen for these studies. This nursery produces coffee seedlings in large scale and keeps the seedlings under the shade of mango and banana trees. Ten coffee bushes about five years old, $90-100 \mathrm{~cm}$ height of the same vegetation were chosen for sampling purposes. During June, 2010 these bushes were artificially infested by different stages of $I$. seychellarum. After settling the infestation, regular half-monthly examinations were conducted for one complete year $\left(15^{\text {th }}\right.$ January, 2011 to $1^{\text {st }}$ January, 2012). The selected bushes were marked and five leaves from each bush were labeled (50 leaves/10 bushes). The different developmental stages of $I$. seychellarum were counted at half-monthly intervals in site by using a 10X lens.

Data obtained from both localities of half-monthly counts were used to represent the total numbers of alive individuals as an index of the insect population. The rate of increase in the population density was calculated by dividing the total numbers of the population in any count over the numbers of the previous one and average of the annual fluctuations which calculated by dividing the maximum number of total population over the minimum one (Bodenheimer, 1951). Also, total numbers of alive individuals in both years were used to estimate the numbers and durations of annual field generations using the method proposed by Audemard and Milaire (1975) and emended by lacob (1977).

\section{b. Effects of four main weather factors on the changes in population density of $I$. seychellarum}

The effects of four main weather factors (maximum, minimum, mean temperatures and mean percentage of relative humidity) on the changes of population density of $I$. seychellarum were carried out during the two years at the two ecosystems. Data of the total population counts were smoothed by their 3-figures running means throughout the whole year and taken as dependent variable $(Y)$. On the other hand, the four weather factors were taken as independent variables; i.e. mean minimum temperature $\left(X_{1}\right)$, mean maximum temperature $\left(X_{2}\right)$, mean temperatures $\left(X_{3}\right)$ and mean percentage of relative humidity $\left(\mathrm{X}_{4}\right)$. Meteorological data were obtained from the Central Laboratory for Agricultural Meteorology, Ministry of Agriculture. Several trials were carried out to investigate the effects of the corresponding data of these four weather factors ( 2 and 4 weeks earlier) on the changes of the population density of this mealybug species. Preliminary results showed that data of these factors four weeks earlier gave promising results.

Statistical analysis procedures were carried out into two steps using the SPSS $^{\circledR}$ software (ver. 16); the first one by applying simple correlation 
Nabil, Dalia Z. et al.

formula to detect the effects of each factor separately. The second step by applying the C-multiplier formula (Fisher, 1950) to investigate the combined effects of the four tested factors, as a group, on the changes in population density of this pest expressed as percentage of explained variance (E.V.\%). The variance ratio "F value" was used as measure of significance for E.V.\%. It was found more convenient to discuss the results for each locality separately.

\section{RESULTS AND DISCUSSION}

\section{Ecological studies on I. seychellarum}

\section{1. a. Under field conditions of Qalyubyia Governorate}

Results obtained are given in Figs. (1 and 2). These results revealed that populations of $I$. seychellarum were found to exist on coffee trees all the year round. The half-monthly counts of total population were fluctuated throughout the year and four peaks of seasonal abundance were recorded in mid-January, $1^{\text {st }}$ of April, $1^{\text {st }}$ of October and mid-November, 2009. The total numbers of insect populations for these peaks were $353,223,386$ and 743 individuals/50 leaves, respectively.

Regarding the number of nymphs in relation to the total insect population, it was obvious that it followed the same trend and recorded four peaks. The maximum number of nymphs was occurred in mid-November, 2009 being 689 nymphs/50 leaves. Other three smaller peaks of nymphs' population occurred in mid-January, mid-August and $1^{\text {st }}$ October, 2009, the half-monthly counts of nymphs were 264,163 and 322 nymphs on 50 leaves, respectively.

The average annual fluctuation as calculated by dividing the maximum total population which reached (743 individuals/50 leaves occurred in midNovember) by the minimum numbers (92 individuals/50 leaves occurred in $1^{\text {st }}$ June) was 8.1 . The rate of increase of half monthly counts as calculated by dividing the total number of insects in any month by that of the preceding one, showed that the highest value was 2.28 which occurred on $1^{\text {st }}$ October, 2009. The half-monthly records of females were found to be less in numbers in comparison with the numbers of nymphs in all counts. This phenomenon probably due to that some adult females were moved to the bushes of trees. Also, adult females recorded four peaks of abundance which occurred in midJanuary, mid-April, Mid-August and $1^{\text {st }}$ October 2009. The total number of females on 50 leaves was $89,48,40$ and 64 females, respectively.

Data shown in Fig. (2) reveal that this pest passed through three field generations; the first began lasted for 90 days (the shortest generation). The second generation lasted for 120 days and the third lasted for 145 days (the longest generation).

\section{1. b. Under nursery conditions at Giza Governorate}

Results obtained are given in Figs (3 and 4). These results showed that populations of $I$. seychellarum were also found to exist on coffee bushes throughout the whole year with four peaks of seasonal abundance. These peaks occurred on mid-January, mid-May, $1^{\text {st }}$ of July and mid-September, 
2011. The total numbers of insect populations were 230, 175, 285 and 261 individuals/50 coffee leaves, respectively.

Regarding the numbers of nymphs' population, it was obvious, that it had three peaks of seasonal abundance which occurred in mid-January, $1^{\text {st }}$ of July and $1^{\text {st }}$ of October, 2011. The total numbers of nymphs on these samples were 209, 239 and 206 nymphs/50 coffee leaves. Also, the numbers of non-ovipositing females followed the same trend and recorded three peaks of seasonal abundance. These peaks occurred on mid-February, $1^{\text {st }}$ of July and mid-August, 2011 and represented by fewer numbers in comparison to those of nymphs. The half-monthly counts of ovipositing females during these samples were 21,46 and 53 individuals/50 coffee leaves, respectively.

The average annual fluctuation which calculated by dividing maximum population (285) which occurred on $1^{\text {st }}$ of July over the minimum population (136) which occurred on $1^{\text {st }}$ of March being 2.1. Also, the highest rate of increase was occurred on $1^{\text {st }}$ of July, 2011 being 1.83. Therefore, it seemed that the favorable time for annual increase of $I$. seychellarum population was extended from $1^{\text {st }}$ July to mid-September, 2011 on coffee bushes under nursery conditions in Giza locality. On comparing these results with main climatic conditions prevailing during that period, it appears that the means temperature were ranged between 28.0 to $32.2^{\circ} \mathrm{C}$ and the mean relative humidity 52 to $60 \%$ on $1^{\text {st }}$ of July and mid-September, respectively. These conditions seemed to be the optimal time for insect reproduction in Giza Governorate.

Data shown in Fig. (4) reveal that, in this locality, the pest also passed through three field generations/year; the first lasted for 95 days. The second generation lasted for 115 days and the third lasted for 120 days.

From these results, it could be concluded that the population of this mealybug was found to occur on coffee trees and bushes in the two localities all the year round. The total population recorded four peaks of seasonal abundance representing three annual overlapping generations its durations differ from one locality to the other.

These results are in harmony with those obtained by other authors in Egypt on other host plants i.e. Saad (1980) on Latania commersoni in Suez; Assem (1990) on sago palm trees in Egypt; Osman (2005) on mulberry trees in Qalyubyia Governorate and Sayed (2008) on Mango trees in Ismailia; while, Hassan and Radwan (2008) reported four annual generations on persimmon, Diospynes kaki trees in Qalyubyia Governorate. Hassan et al. (2012), Mesbah et al. (2012), Moustafa (2012) and Salman and Bakry (2012) had the same results.

These results are also closely related to the findings of Newbery and Hill (1981) who stated that I. seychellarum had one peak of seasonal abundance on beach naubaka, Scarvola sericea trees in Aldobora Atoll Island, Seychelles. Mangoud (2000) stated that this mealybug species recorded 2-3 peaks of seasonal abundance on apple trees in Egypt. These peaks were occurred during late June, late October and mid-December. Tawfik and Mohammed (2001) recorded two peaks of seasonal abundance per year for this species on mulberry trees in Egypt. These peaks occurred in 
June and August. El-Serafi et al. (2004) stated that $I$. seychellarum had two annual peaks of seasonal abundance on guava trees in Dakahliya Governorate, Egypt. The highest peak was occurred by the end of August; while the second was occurred on the end of March. Abdel-Rahman et al. (2007) recorded four annual peaks of seasonal abundance for this species on mango trees in Giza, Egypt. These peaks occurred on March (the smallest one), June, August (the highest one) and September/October.

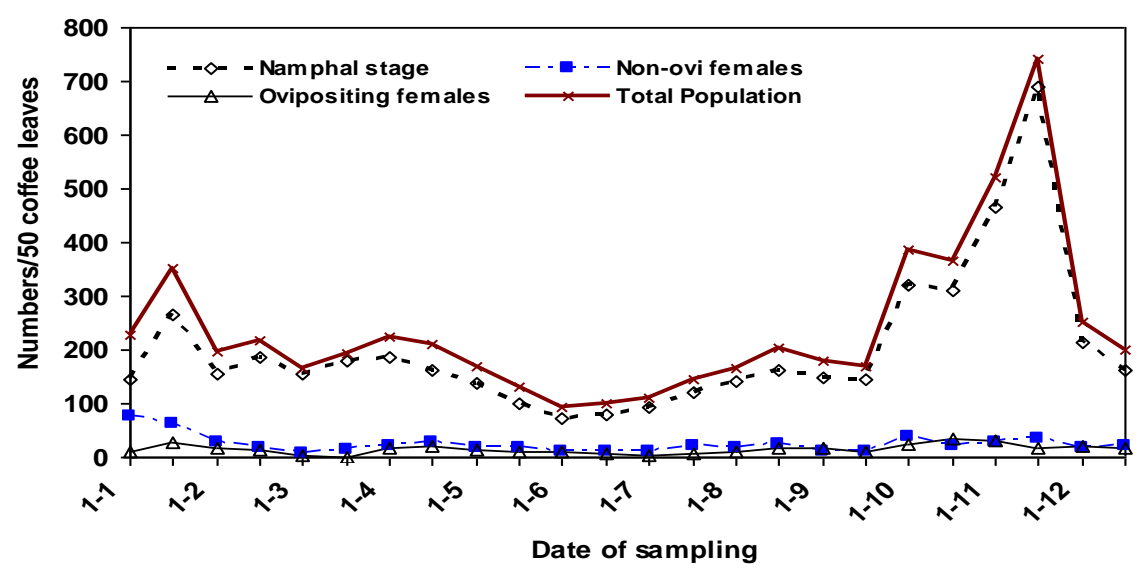

Fig. (1): The fluctuations in the different developmental stages of $I$. seychellarum on 50 coffee leaves at Qalyubyia Governorate during 2009.

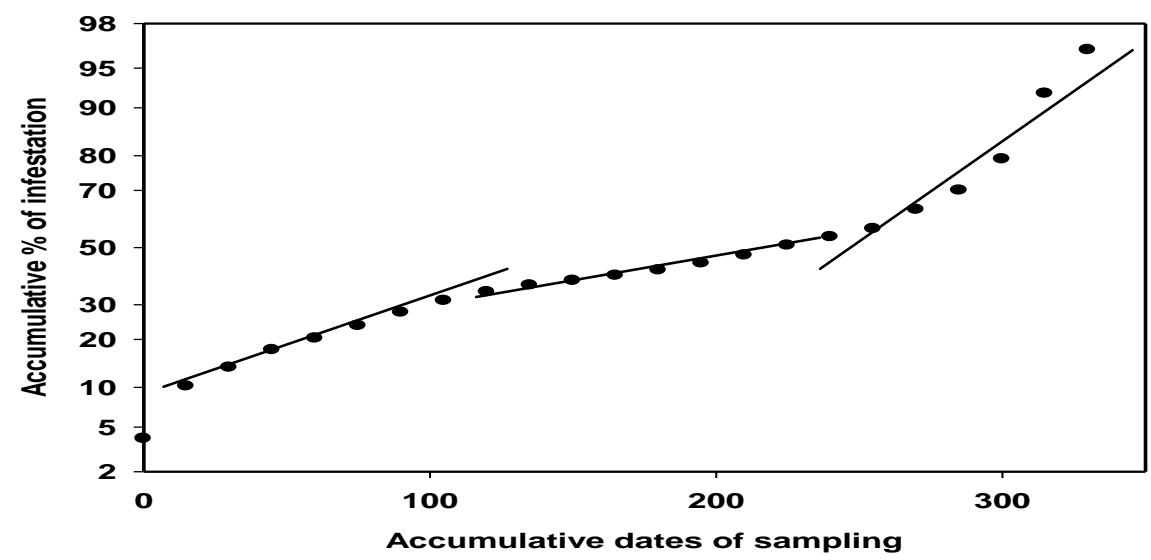

Fig. (2): Numbers and durations of field generations of $I$. seychellarum according to Audemard and Milaire (1975) and lacob (1977) at Qalyubyia Governorate during 2009.

Bakry (2009) stated that $I$. seychellarum had three annual peaks of seasonal abundance on mango trees in Qena Governorate, Egypt. These peaks occurred on May, August and November. 


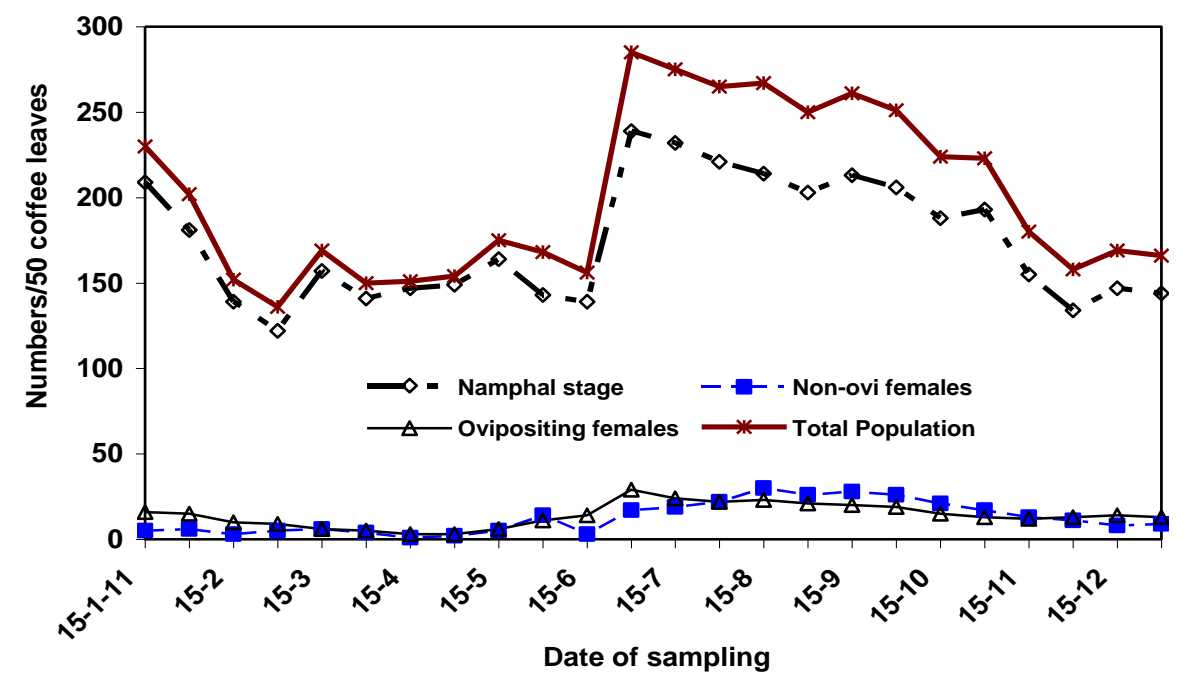

Fig. (3): The fluctuations in the different developmental stages of $I$. seychellarum on 50 coffee leaves at Giza Governorate during 2011.

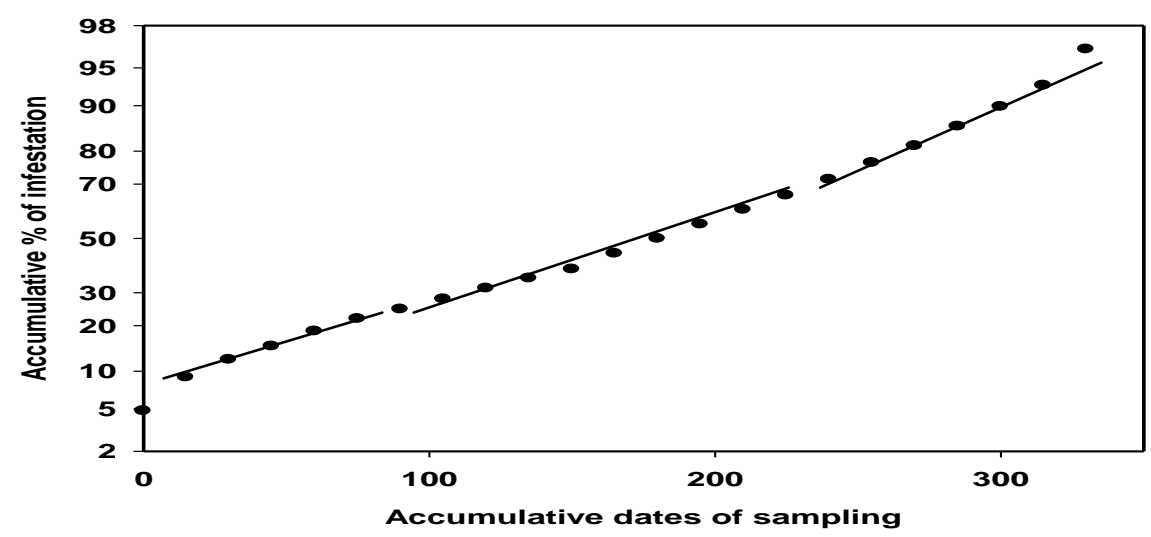

Fig. (4): Numbers and durations of field generations of $I$. seychellarum according to Audemard and Milaire (1975) and lacob (1977) at Giza Governorate during 2011.

2. Effects of four main weather factors on the changes in population density of $I$. seychellarum, at two ecosystems during two years

Data of four main weather factors (maximum, minimum, mean temperatures and mean percentage of relative humidity) and the changes of population density of $I$. seychellarum along with their 3 -figures running means throughout the whole year in both localities are shown in Tables (1 and 2). 
Nabil, Dalia Z. et al.

Table (1): Half-monthly counts of the total population of $I$. seychellarum on 50 coffee leaves with 3-figure running mean with the corresponding data of three main weather factors at Qalyubyia Governorate during 2009

\begin{tabular}{|c|c|c|c|c|c|c|c|}
\hline $\begin{array}{c}\text { Sampling } \\
\text { Date }\end{array}$ & $\begin{array}{c}\text { Total } \\
\text { Population }\end{array}$ & $\begin{array}{c}\text { Rate of } \\
\text { increase }\end{array}$ & $\begin{array}{c}\text { Running } \\
\text { mean of } \\
\text { the } \\
\text { population }\end{array}$ & $\begin{array}{c}\text { Min. } \\
\text { Temp. }\end{array}$ & $\begin{array}{c}\text { Max. } \\
\text { Temp. }\end{array}$ & $\begin{array}{c}\text { Mean } \\
\text { Temp. }\end{array}$ & R.H.\% \\
\hline $\mathbf{1 5 / 1 2 / 2 0 0 8}$ & --- & & --- & 14.2 & 27.7 & 21.0 & 58 \\
\hline $\mathbf{1 / 1 / 2 0 0 9}$ & 229 & --- & --- & 12.3 & 21.9 & 17.1 & 61 \\
\hline $\mathbf{1 5 / 1}$ & 353 & 1.54 & 260.0 & 11.0 & 20.4 & 15.7 & 59 \\
\hline $\mathbf{1 / 2}$ & 198 & 0.56 & 256.0 & 11.5 & 22.1 & 16.8 & 55 \\
\hline $\mathbf{1 5 / 2}$ & 217 & 1.10 & 193.3 & 11.5 & 23.4 & 17.5 & 54 \\
\hline $\mathbf{1 / 3}$ & 165 & 0.76 & 192.0 & 10.6 & 22.0 & 16.3 & 56 \\
\hline $\mathbf{1 5 / 3}$ & 194 & 1.18 & 194.0 & 11.0 & 22.0 & 16.5 & 57 \\
\hline $\mathbf{1 / 4}$ & 223 & 1.15 & 209.3 & 11.4 & 23.4 & 17.4 & 58 \\
\hline $\mathbf{1 5 / 4}$ & 211 & 0.95 & 201.0 & 11.6 & 25.8 & 18.7 & 57 \\
\hline $\mathbf{1 / 5}$ & 169 & 0.80 & 170.0 & 12.6 & 28.3 & 20.5 & 56 \\
\hline $\mathbf{1 5 / 5}$ & 130 & 0.77 & 130.3 & 13.1 & 28.1 & 20.6 & 57 \\
\hline $\mathbf{1 / 6}$ & 92 & 0.70 & 107.3 & 13.3 & 29.2 & 21.2 & 59 \\
\hline $\mathbf{1 5 / 6}$ & 100 & 1.09 & 100.3 & 14.2 & 31.5 & 22.8 & 59 \\
\hline $\mathbf{1 / 7}$ & 109 & 1.09 & 118.0 & 14.9 & 33.2 & 24.1 & 58 \\
\hline $\mathbf{1 5 / 7}$ & 145 & 1.33 & 140.0 & 14.2 & 33.3 & 23.7 & 60 \\
\hline $\mathbf{1 / 8}$ & 166 & 1.14 & 171.3 & 14.1 & 33.4 & 23.7 & 62 \\
\hline $\mathbf{1 5 / 8}$ & 203 & 1.22 & 182.3 & 14.8 & 33.5 & 24.2 & 62 \\
\hline $\mathbf{1 / 9}$ & 178 & 0.88 & 183.3 & 16.4 & 32.9 & 24.6 & 62 \\
\hline $\mathbf{1 5 / 9}$ & 169 & 0.95 & 244.3 & 17.8 & 32.8 & 25.3 & 61 \\
\hline $\mathbf{1 / 1 0}$ & 386 & 2.28 & 307.3 & 19.5 & 32.2 & 25.9 & 62 \\
\hline $\mathbf{1 5 / 1 0}$ & 367 & 0.95 & 427.7 & 19.9 & 31.3 & 25.6 & 62 \\
\hline $\mathbf{1 / 1 1}$ & 521 & 1.42 & 543.7 & 19.6 & 30.6 & 25.1 & 60 \\
\hline $\mathbf{1 5 / 1 1}$ & 743 & 1.43 & 505.3 & 17.4 & 27.7 & 22.5 & 60 \\
\hline $\mathbf{1 / 1 2}$ & 252 & 0.34 & 398.3 & 15.6 & 24.7 & 20.2 & 63 \\
\hline $\mathbf{1 5 / 1 2 / 2 0 0 9}$ & 200 & 0.79 & 211.3 & 14.1 & 22.6 & 18.3 & 62 \\
\hline $\mathbf{A v}$ & & & & & & \\
\hline
\end{tabular}

Average annual fluctuation $=8.1$ 
Table (2): Half-monthly counts of the total population of $I$. seychellarum on 50 coffee leaves with 3-figure running mean with the corresponding data of three main weather factors at Giza Governorate during 2011

\begin{tabular}{|c|c|c|c|c|c|c|c|}
\hline $\begin{array}{c}\text { Sampling } \\
\text { Date }\end{array}$ & $\begin{array}{c}\text { Total } \\
\text { Population }\end{array}$ & $\begin{array}{c}\text { Rate of } \\
\text { increase }\end{array}$ & $\begin{array}{c}\text { Running } \\
\text { mean of the } \\
\text { population }\end{array}$ & $\begin{array}{c}\text { Min. } \\
\text { Temp. }\end{array}$ & $\begin{array}{c}\text { Max. } \\
\text { Temp. }\end{array}$ & $\begin{array}{c}\text { Mean } \\
\text { Temp. }\end{array}$ & R.H.\% \\
\hline $\mathbf{1 / 1 / 2 0 1 1}$ & --- & & --- & 12.3 & 22.9 & 17.6 & 62 \\
\hline $\mathbf{1 5 / 1}$ & 230 & --- & --- & 10.3 & 20.6 & 15.4 & 61 \\
\hline $\mathbf{1 / 2}$ & 202 & 0.78 & 194.7 & 9.3 & 19.8 & 14.6 & 62 \\
\hline $\mathbf{1 5 / 2}$ & 152 & 0.88 & 163.3 & 10.7 & 21.2 & 15.9 & 64 \\
\hline $\mathbf{1 / 3}$ & 136 & 0.75 & 152.3 & 11.3 & 22.0 & 16.6 & 56 \\
\hline $\mathbf{1 5 / 3}$ & 169 & 0.89 & 151.7 & 11.3 & 22.8 & 17.0 & 52 \\
\hline $\mathbf{1 / 4}$ & 150 & 1.24 & 156.7 & 12.0 & 24.2 & 18.1 & 55 \\
\hline $\mathbf{1 5 / 4}$ & 151 & 0.89 & 151.7 & 13.2 & 25.6 & 19.4 & 54 \\
\hline $\mathbf{1 / 5}$ & 154 & 1.00 & 160.0 & 15.2 & 27.6 & 21.4 & 50 \\
\hline $\mathbf{1 5 / 5}$ & 175 & 1.02 & 165.7 & 17.0 & 28.9 & 22.9 & 49 \\
\hline $\mathbf{1 / 6}$ & 168 & 1.14 & 166.3 & 18.7 & 31.3 & 25.0 & 49 \\
\hline $\mathbf{1 5 / 6}$ & 156 & 0.96 & 203.0 & 20.9 & 34.2 & 27.5 & 48 \\
\hline $\mathbf{1 / 7}$ & 285 & 0.93 & 238.7 & 21.7 & 34.4 & 28.0 & 52 \\
\hline $\mathbf{1 5 / 7}$ & 275 & 0.97 & 275.0 & 22.5 & 35.0 & 28.8 & 55 \\
\hline $\mathbf{1 / 8}$ & 265 & 0.96 & 269.0 & 23.8 & 36.6 & 30.2 & 57 \\
\hline $\mathbf{1 5 / 8}$ & 267 & 1.01 & 260.7 & 24.2 & 36.1 & 30.1 & 60 \\
\hline $\mathbf{1 / 9}$ & 250 & 0.94 & 259.3 & 23.6 & 35.3 & 29.5 & 58 \\
\hline $\mathbf{1 5 / 9}$ & 261 & 1.04 & 254.0 & 23.5 & 35.2 & 29.3 & 58 \\
\hline $\mathbf{1 / 1 0}$ & 251 & 0.96 & 245.3 & 22.8 & 34.0 & 28.4 & 58 \\
\hline $\mathbf{1 5 / 1 0}$ & 224 & 0.89 & 232.7 & 20.9 & 32.5 & 26.7 & 55 \\
\hline $\mathbf{1 / 1 1}$ & 223 & 1.00 & 209.0 & 18.1 & 29.1 & 23.6 & 55 \\
\hline $\mathbf{1 5 / 1 1}$ & 180 & 0.81 & 187.0 & 15.5 & 25.8 & 20.7 & 61 \\
\hline $\mathbf{1 / 1 2}$ & 158 & 0.88 & 169.0 & 12.8 & 22.9 & 17.8 & 66 \\
\hline $\mathbf{1 5 / 1 2}$ & 169 & 1.07 & 164.3 & 11.1 & 21.0 & 16.1 & 70 \\
\hline $\mathbf{1 / 1 / 2 0 1 2}$ & 166 & 0.98 & --- & 10.0 & 20.6 & 15.3 & 69 \\
\hline $\mathbf{A v}$ & & & & & & \\
\hline
\end{tabular}

Average annual fluctuation $=2.1$

\section{2. a. Qalyubyia ecosystem}

Results of statistical analysis are given in Table (3). The mean minimum temperature had a positive and highly significant effect on the population density of $I$. seychellarum during 2009 . The correlation coefficient value $(r)$ was $0.606^{\star * *}$. The unit effect (b) was 28.6 individuals. The main period of seasonal activity of this species extended from April to half of November throughout the year. During this period the mean minimum temperature ranged between $11.4-19.9^{\circ} \mathrm{C}$. On the other hand, mean maximum temperature had positive insignificant effect on the changes of the population of this species. The correlation coefficient value $(0.117)$ was insignificant.

The effect of mean percentage of relative humidity was also insignificant on the changes of population density of $I$. seychellarum on coffee trees at Qalyubyia Governorate. The correlation coefficient value was 0.241. 
Nabil, Dalia Z. et al.

Results of statistical analysis (Table 3) revealed that the four main weather factors, four weeks earlier, were responsible as a group of $56.8 \%$ (the explained variance) of the total effect on the changes in the population density of $I$. seychellarum on coffee trees at Qalyubyia Governorate. The variance ratio was $6.58(P=0.002)$.

\section{2. b. Giza ecosystem}

Results of statistical analysis are given in Table (4). The effect of mean minimum temperature was positive and highly significant on the numbers of alive individuals of $I$. seychellarum during 2011 at Giza Governorate. The correlation coefficient value was $0.787^{\star * *}$ and the unit effect (b) was 10.5 individuals. The main period of seasonal activity of this species was extended from mid May to mid November throughout the year. During this period the mean minimum temperature ranged between $15.5-24.2^{\circ} \mathrm{C}$. The mean maximum temperature also showed a positive and highly significant effect. The correlation coefficient value was $0.774^{\star * *}$. The mean maximum temperature ranged between $25.8-36.6^{\circ} \mathrm{C}$.

Mean percentage of relative humidity had a negative insignificant effect on the changes of population density of $I$. seychellarum on coffee bushes at Giza Governorate. The correlation coefficient value was -0.298 .

The combined effects of these weather factors (Table 4) revealed that the four main weather factors four weeks earlier were responsible, as a group for $65.9 \%$ of the changes in the population density of $I$. seychellarum on coffee bushes at Giza Governorate. The variance ratio (9.16) was significant $(P=0.0002)$.

From the above-mentioned results it could be stated that the changes in population density of $I$. seychellarum were not related to the single effect of each factor separately but mostly due to the simultaneous effects of the four selected main weather factors, as a group. The remaining unexplained variance may be due to the influence of other unconsidered factors specially phenology of coffee trees.

Table (3): Results of statistical analysis (simple correlation, partial regression and analysis of variance) on the relationship between the effects of four weather factors, four weeks earlier, on the population of $I$. seychellarum on coffee trees at Qalyubyia Governorate during 2009.

\begin{tabular}{|c|c|c|c|c|c|c|c|}
\hline \multirow{2}{*}{\begin{tabular}{|l} 
Tested \\
variables
\end{tabular}} & \multicolumn{3}{|c|}{ Simple correlation } & \multicolumn{3}{|c|}{ Regression values } & \multirow{3}{*}{$\begin{array}{c}\text { Explained } \\
\text { Variance } \\
56.8 \%\end{array}$} \\
\hline & $" r "$ & Prob. & "b" & s.e. & $" t "$ & Prob. & \\
\hline Min. Temp. & 0.606 & $1 \%$ & 28.6 & 375.12 & 0.850 & 0.405 & \\
\hline Max. Temp. & 0.117 & ---- & ---- & 370.07 & 0.667 & 0.512 & "F" value \\
\hline $\begin{array}{l}\text { Mean } \\
\text { Temp. }\end{array}$ & 0.328 & ---- & ---- & 740.88 & 0.707 & 0.488 & 6.577 \\
\hline R.H. \% & 0.241 & ---- & ---- & 11.25 & 1.555 & 0.135 & \\
\hline
\end{tabular}


Table (4): Results of statistical analysis (simple correlation, partial regression and analysis of variance) on the relationship between the effects of four weather factors, four weeks earlier, on the population of $I$. seychellarum on coffee bushes at Giza Governorate during 2011.

\begin{tabular}{|c|c|c|c|c|c|c|c|}
\hline \multirow{2}{*}{\begin{tabular}{|l} 
Tested \\
variables
\end{tabular}} & \multicolumn{3}{|c|}{ Simple correlation } & \multicolumn{3}{|c|}{ Regression values } & \multirow{3}{*}{$\begin{array}{c}\text { Explained } \\
\text { Variance } \\
65.9 \%\end{array}$} \\
\hline & $" r "$ & Prob. & "b" & s.e. & $" t "$ & Prob. & \\
\hline Min. Temp. & 0.787 & $1 \%$ & 10.46 & 216.98 & 1.24 & 0.229 & \\
\hline Max. Temp. & 0.774 & $1 \%$ & 9.16 & 207.77 & 1.40 & 0.179 & "F" value \\
\hline $\begin{array}{l}\text { Mean } \\
\text { Temp. }\end{array}$ & 0 & $1 \%$ & 2 & 422.64 & 1.35 & 0 & 9.16 \\
\hline R.H. \% & -0.298 & ---- & ---- & 2.77 & 0.57 & 0.573 & \\
\hline
\end{tabular}

These results are in harmony with those obtained by El-Borollsy et al. (1990). They stated that the changes in the population density of $I$. seychellarum on sago palm were significantly affected by the changes in both temperature and relative humidity. Osman (2005) stated that daily means of maximum, minimum temperatures and percentage of relative humidity could govern the seasonal activity of $l$. seychellarum on mulberry trees. AbdelRahman et al. (2007) showed significant positive correlation with mean temperature and insignificant negative correlation with mean percentage of relative humidity on mango trees in Egypt.

\section{REFRENCES}

Abdel-Rahman, M. M.; M. S. Salem; S. F. M. Moussa; M. E. Nour and Maha I. E. L. Said (2007). Seasonal fluctuation of the Seychelles fluted scale, Icerya seychellarum (Westwood) on four mango cultivars in Egypt. Egypt. J. Agric. Res.; 85 (1): 77 - 88.

Assem, S. M. (1990). Survey and ecological studies on some insects attacking certain ornamental plants. Ph.D. Thesis, Fac. Agric., Cairo, Egypt; 202 pp.

Audemard, H. and H. G. Milaire (1975). Le pegeage du Carpocapsa (Laspeyresia) pomonella L. avec une pheromone sexuelle de synthese: premiers resultata utilisables pour 1 , estimation des populations et la conduite de la lulte. Ann. Zool. Ecol. Anim.; 7 (1): 61-80.

Bakry, M. M. (2009). Studies on some scale insects and mealybugs infesting mango trees in Qena Governorate. M. Sc. Thesis, Fac. Agric., Minia Univ.; 204 pp.

Bodenheimer, F. S. (1951). Citrus Entomology in the Middle East, with special reference to Egypt, Iran, Iraq, Syria, Palestine, Turkey. Gravenhade, Junk, $663 \mathrm{p}$.

Camargo M. B. P. (2010). The impact of climatic variability and climate change on Arabic coffee crop in Brazil. Bragantia, 69: 239-247.

El-Borollosy, F. M.; M. M. El Bolok; Shadia, M. Assem and I. Ezz (1990). Ecological studies on the ornamental palm mealybug, Icerya 
seychellarum (Westwood), (Margarodidae:Homoptera) on a Cycus revoluta Thumb (Cycadaceae). Bull. Soc. Ent. Egypt.; 69: 257 - 269.

El-Serafi, Hala; A. A. Ghanim; A. H. El-Heneidy and M. K. El-Sherbenieb (2004). Ecological studies on certain Insects at Mansoura District. Egypt. J. Biol. Pest Cont., 14(1): $77-85$.

Fisher, R. A. (1950). Statistical methods for research workers. Oliver and Boyed. Edinburgh and London.

Fletcher, W. W. (1974). The pest war. Blackwell Oxford Press, 218 pp.

Hassan, Nagwa A. and Radwan, Sawsan G. (2008). Population dynamics of Icerya seychellarum (Homoptera: Margarodidiae) and Rodolia cardiralis (Coleoptera: Coccinellidae) on persimmon (Diospyros kakı) at Qalubyia Governorate. Egypt. J. Agric. Res.; 86(3): 1015-1027.

Hassan, N. A.; S. G. Radwan and O. M. N. El-Sahn (2012). Common scale insects (Hemiptera:Coccoidea)in Egypt. Egypt. Acad. J. Biolog. Sci.; 5 (3): 153-160.

Ibrahim, I. M.; Zeinab Hamdy and M. F. Ashmay (1987). Coffee adaptation to Egyptian climate. Agric. Res. Rev.; 65 (3): 397-408.

lacob, N. (1977). Un model matimatic pentru stabilirea limitelor economic de tolerenta a atacalui molilor fructilor in lupte integrata. Anal. Instit. Cerc. Prot. Plant; 15-179.

International Coffee Organization (ICO) (2012) Trade Statistics. At: http://www.ico.org/trade statistics.asp? section=Statistics.

Mangoud, A. A. H. (2000): Intergraded pest management of apple trees. Ph. D. Thesis, Cairo Univ., Egypt, 255 pp.

Mesbah, H. A.; K. S. Moursi; A. K. Mourad; E. A. Zakzouk and R. S. AbdelFattah (2012). Ecological studies on the common white mealybug, Icerya seychellarum (Hemiptera:Monophlebidae) associated with Dodonia viscosa in Alexandria, Egypt. Egypt. Acad. J. Biolog. Sci.; 5 (3): 27-31.

Moustafa, Mona (2012). Scale insects (Coccidae:Hemiptera) infested citrus trees and their natural enemies with a key of these pests in Egypt. Egypt. Acad. J. Biolog. Sci.; 5 (1): 1-23.

Newbery, D. M. C. and M. G. Hill (1981). Numerical classification of "mixed scrub" vegetation on Aldabra Atoll. Atoll Res. Bull.; 246: 1 - 13.

Osman, E. A. (2005). Studies on homopterous insect pests infesting mulberry tree in relation with Bambyx mori; L. (Bombycidae: Lepidoptera) silk production. Ph. D. Thesis, Fac. Agric., Cairo Univ.; 160 pp.

Saad, A. G. A. (1980). Studies on palm trees insects belonging to superfamily Coccoidea in Egypt. Ph. D. Thesis., Fac. Agric., Al-Azhar Univ.; 188 pp.

Salman, A. M. A. and M. M. S. Bakry (2012). Relationship between the rate of infestation with the mealybug, Icerya seychellarum (Westwood) (Margarodidae: Homoptera) and the yield loss of seedy balady mango trees at Luxor Governorate. World Rural Observations, 4 (4): 50-56.

Sauer, J. D. (1993). Historical Geography of Crop Plants: a select roster. Boca Raton, Florida, U.S.A.: CRC Press.

Sayed, A. M. M. (2008). Studies on the mealybugs infesting some fruit trees and its natural enemies. Ph. D. Thesis, Fac. Agric., Al-Azhar Univ.; 312 pp. 
Tawfik, M. H. and Z. K. Mohammed (2001). Ecological studies of two scale insects (Hemiptera:Coccoidea) on Morus alba in Egypt. Bollettino di Zoologia Agrariae di Bachicoltura, 33(3): 267 - 273.

Waller, J. M.; M. Bigger and R. J. Hillcocks (2007). Coffee pests \& diseases and their management. CABI Publications, $450 \mathrm{pp}$

Icerya seychellarum (Westwood) بعض المظاهر البيئية لحشرة

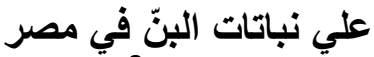

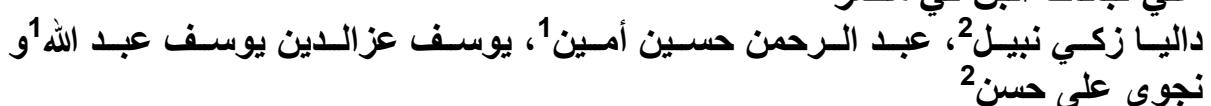

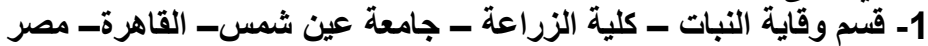
2- قسم الحشرات القثرية والبق الاقيقى - معهل بحوث وقاية النباتات ـ الجيزة - مصر مصر

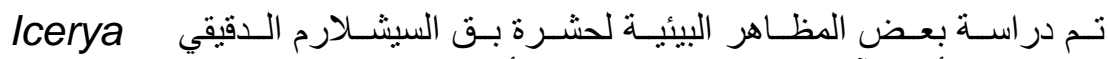
seychellarum

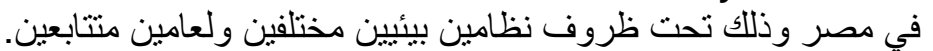

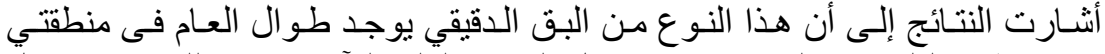

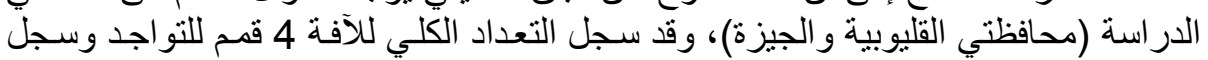
للحشرة 3 أجيال متداخلة في العام في كلتا المحافظتنين.

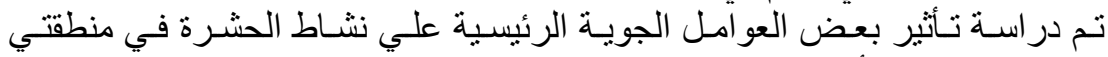

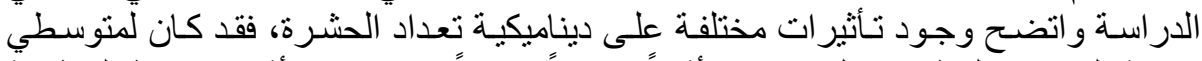

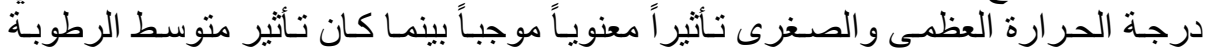

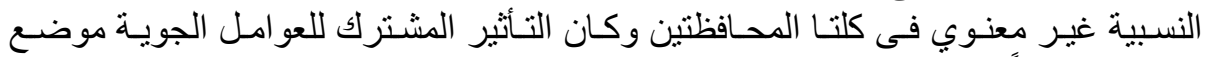

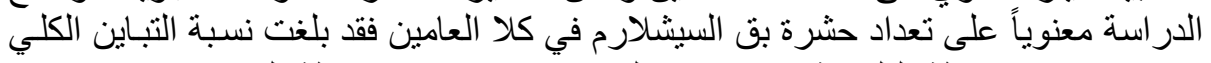
56.8\% فى محافظة القليو بية (2009) وبلغت 65.9\% فى محافظة الجيزة (2011).

كلية الزراعة - جامعة المنصورة

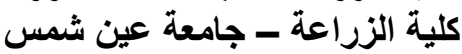

قام بتحكيم البحث

أ.د / أبد البد البديع عبد الحميد غانم

أ.د / محمد سالم عبد الواحد البد عان 